\title{
Localized Bullous Pemphigoid on the Site of Knee Arthroplasty: A Case Report
}

\author{
Lucija KOSI ${ }^{1}$, Jelena PERIĆ ${ }^{1}$, Milica PANTOVIĆ ${ }^{1}$, Gorana BIJELIĆ ${ }^{1}$, \\ Jelica VUKIĆEVIĆ SRETENOVIĆ ${ }^{1,2}$, Dušan ŠKILJEVIĆ ${ }^{1,2^{*}}$ \\ 1Clinic of Dermatovenereology, Clinical Center of Serbia; Belgrade, Republic of Serbia \\ ${ }^{2}$ Clinic of Dermatovenereology, Clinical Center of Serbia; Department of \\ Dermatovenereology, School of Medicine, University of Belgrade; Republic of Serbia \\ ${ }^{*}$ Correspondence: Dušan Škiljević, e-mail: dusanskiljevic@yahoo.com
}

UDK 616.527:616.728.3-089-06

\author{
DE GRUYTER \\ OPEN
}

\begin{abstract}
Localized bullous pemphigoid is a rare variant of bullous pemphigoid, and its exact etiopathogenesis is yet to be elucidated. We present a case of a 74-year-old Caucasian male with a 3-month history of skin lesions that appeared 9 months after he underwent a knee arthroplasty. Dermatological examination showed several pruritic tense bullae on the right knee, localized around the surgical scar, as well as erosions covered with crusts. The diagnosis of localized bullous pemphigoid was confirmed by direct immunofluorescence test (conventional and split-skin). The patient was treated with potent topical steroids, which led to complete resolution of cutaneous lesions.

We suppose that the occurrence of localized bullous pemphigoid in our patient may be explained by the concept of "immunocompromised district" in which one disease (surgery) caused an immunological alteration which is a predisposing factor for the development of secondary disease such as localized bullous pemphigoid.
\end{abstract}

\section{Key words}

Pemphigoid, Bullous; Skin Diseases; Cicatrix; Immunocompromised Host; Clobetasol; Arthroplasty, Replacement, Knee

$\mathrm{B}$ ullous pemphigoid (BP) arising on the site of skin injuries, has intrigued the researchers ever since the first description by Sneddon and Church in 1955 (1). Types of injury that can lead to BP vary greatly, among them, surgical procedures such as arthroplasty, are infrequently reported $(2,3)$. Some authors attribute this rare form of disease to a novel concept in dermatology, so called "immunocompromised district" (ICD) (4).

\section{Case report}

We present a case of a 74-year-old Caucasian male who was referred to our Clinic for itching and bullous eruptions that developed on his right knee three months earlier. He was otherwise healthy, except for hypertension, which was treated for several years with the same medications (fosinopril, acetylsalicylic acid and propafenone). His history was also significant for orthroprosthesis of the right knee; due to degenerative changes, a total prosthesis was implanted nine months prior to skin lesions. The patient received systemic and topical antibiotic therapy (gentamicin injections, and topical bacitracin and neomycin), but without favorable results.

Skin examination revealed several tense bullae on erythematous skin, as well as erosions covered with crusts and scars, whereas the patient's main complaint was itching. No milia were seen. The lesions were localized on the incision scar from the above-mentioned orthopedic intervention, as well as on the surrounding skin (Figure 1).

Laboratory tests were not significant, except 


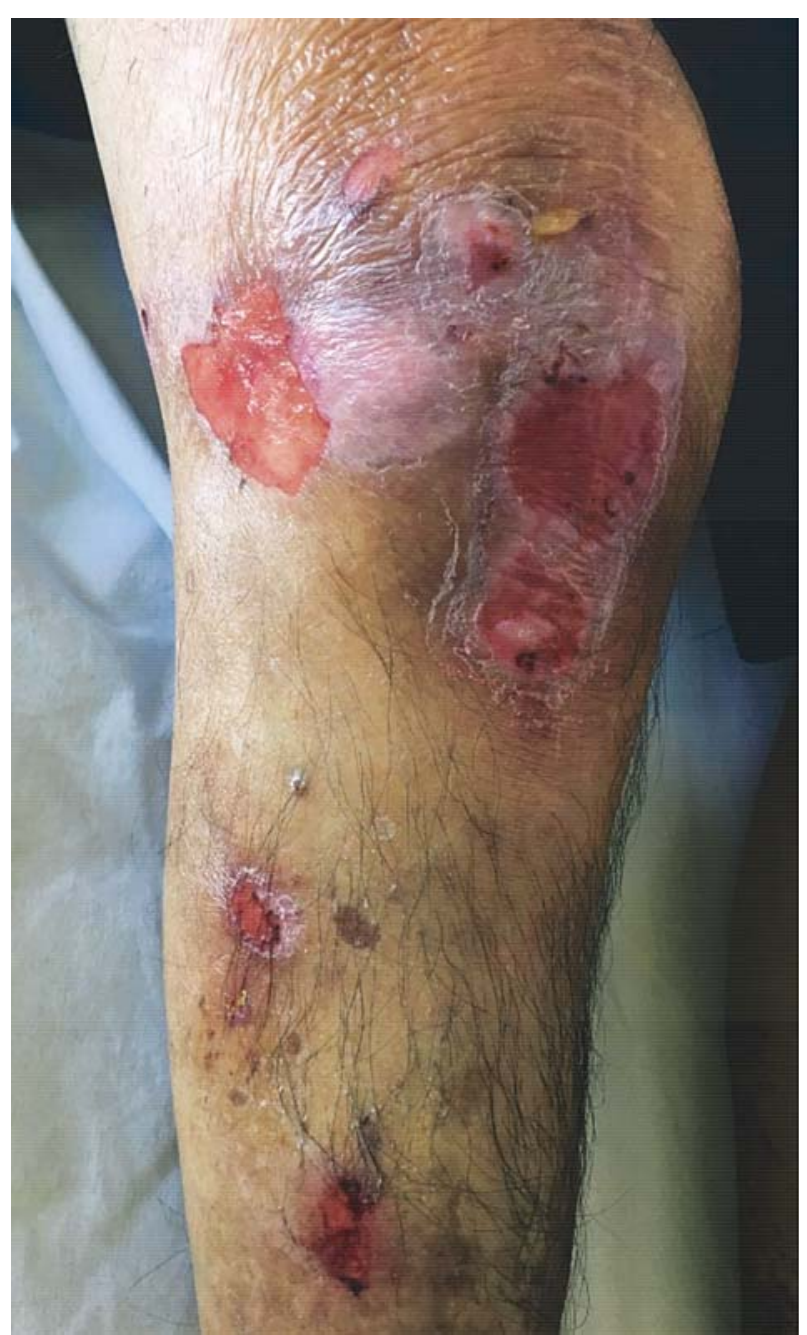

Figure 1. Tense bullae, erosions and crusts on the incision scar site after total knee prosthesis

for: elevated erythrocyte sedimentation rate of 48 $\mathrm{mm} / \mathrm{h}$ and C-reactive peptide of $31.5 \mathrm{mg} / \mathrm{l}$ (normally $<6 \mathrm{mg} / \mathrm{l}$ ). Other test results, for neoplastic processes, such as tumor markers, chest X-ray and abdominal ultrasound, were all unremarkable.

Histological analysis of perilesional skin biopsy specimens was performed by direct immunofluorescence (DIF), which revealed linear deposits of IgG and C3c at the basement membrane zone (BMZ) (Figure 2a). Also, direct immunofluorescence using the salt-split skin (DIF-SS) technique with $1 \mathrm{~mol} / \mathrm{L}$ sodium chloride, revealed linear deposits of the same immunoreactants on the epidermal side („roof”) of the split (Figure 2b), which was consistent with the diagnosis of bullous pemphigoid.
Therapy was initiated by using only potent topical corticosteroids, $0.05 \%$ clobetasol propionate ointment twice a day, because of the localized nature of patient's condition, which lead to complete resolution of skin lesions over the course of eight weeks (Figure 3). No recurrence was observed during a 3-month follow-up.

\section{Discussion}

Bullous pemphigoid is an acquired, autoimmune disease confined to the skin, characterized by formation of autoantibodies which are directed towards components of hemidesmosomes in the basement membrane (5). It is the most common autoimmune bullous disease in Western Europe and North America (6), and probably in most countries of the world (5), which affects mostly the elderly (7). The reported incidence varies greatly among different countries: from $0.25 / 100.000$ inhabitants per year in Romania (6), through 2.2/100 000 inhabitants in France or 2.4/100.000 persons per year in the United States (8), to $4.3 / 100000$ persons per year in the United Kingdom (9). The incidence appears to be increasing in the last two decades $(8,9)$, which may be attributed to greater proportion of older persons in the population (9), or to increasing incidence of neurological diseases, and use of certain medications which are implicated as risk factors for development of BP (10).

Generally, it is thought that BP occurs as a result of delicate interaction between genetic predisposition and various inducing factors (11). As for genetic factors of BP, the strongest association has been documented for human leukocyte antigen $\mathrm{DQ} \beta 1^{*} 0301$ which was observed in $90 \%$ of patients with BP in one of the first studies that tackled this matter (12). Among triggering factors which can be identified in only $15 \%$ of cases (2), several different factors have been implied, such as drug intake (i.e. furosemide) (7), viral infections (6), systemic diseases - malignancy (7), diabetes mellitus (11), and physical trauma (4).

Bullous pemphigoid arising on the site of skin injury firstly appears as a localized form, regardless of the type of physical trauma causing the skin injury. Later on, it remains confined to the particular body area (as it was the case in our patient), or it becomes generalized (3), which appears to be more common (6). 


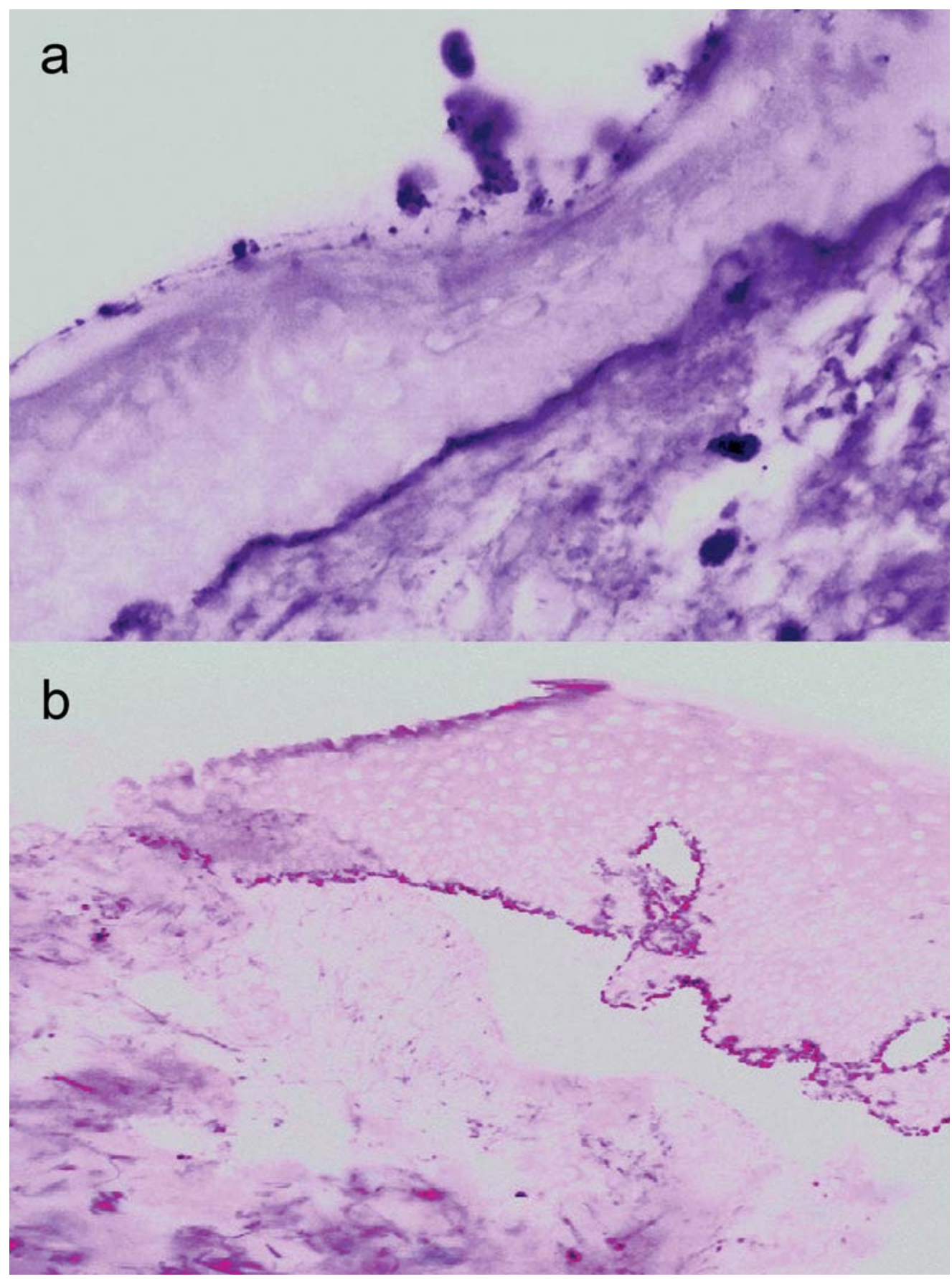

Figure 2. Direct immunofluorescence microscopy of perilesional skin showing IgG and C3c deposits at the epidermal-dermal junction; (b) Direct immunofluorescence on salt-split skin shows IgG and C3c deposits confined to the epidermal side of the split skin

Another possibility is observed when localized lesions develop in a patient with pre-existing generalized BP in remission, leading to conclusion that $\mathrm{BP}$ can be exacerbated by trauma (13). In this particular sense, trauma includes the following: radiotherapy and phototherapy (either UVB or psoralen with UVA) (14); thermal or chemical burns (6); skin grafting (15); simple skin biopsy (13); cellulitis (16). Cases of 


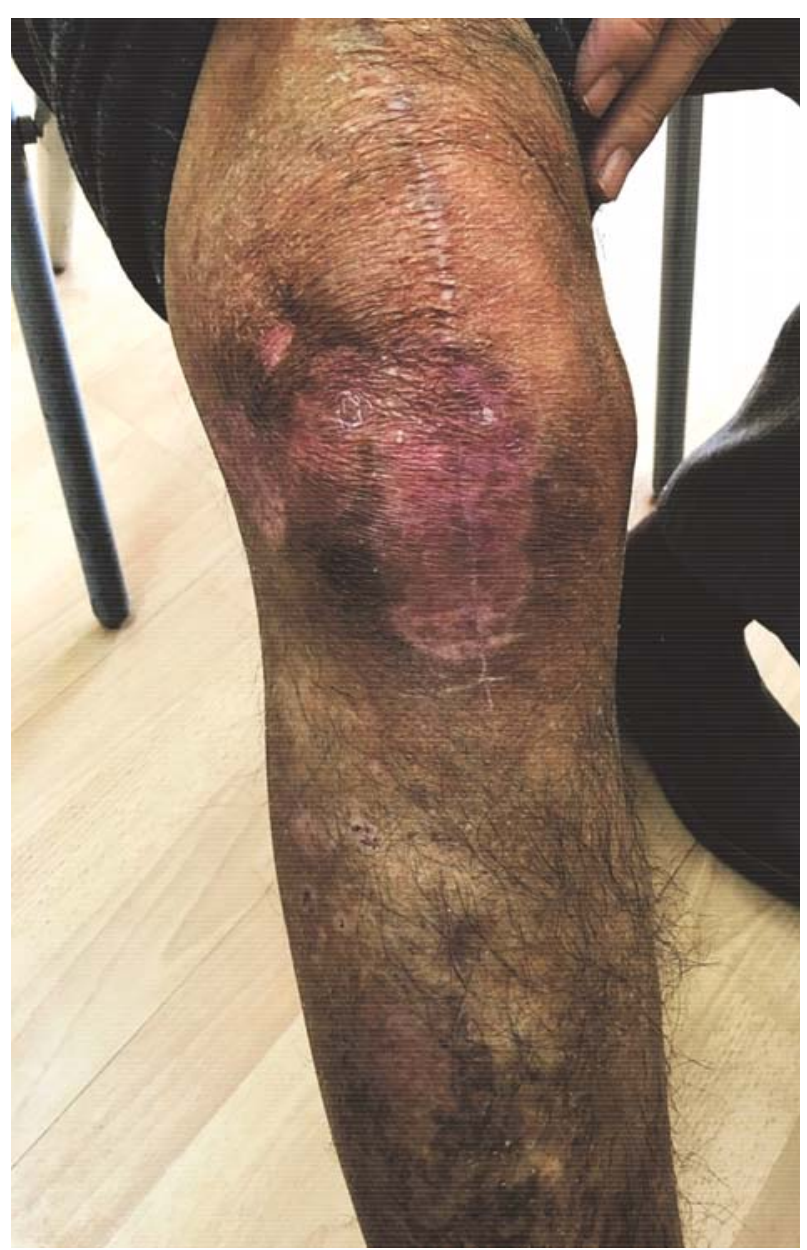

Figure 3. Complete resolution of bullous lesions at the follow-up visit eight weeks later

BP after surgical procedures such as arthroplasty as in our case $(2,3)$, internal fixation of skeletal fractures (17), amputation stumps (13), incisional hernia (14), vascular grafting (7), percutaneous gastrostomy or urostomy (2) etc., are well documented in the literature. Time elapsed from the injury and development of skin lesions varies greatly, ranging from as little as few hours (6) to over 20 years (16).

Several hypotheses have been proposed regarding the pathogenesis of trauma-induced BP. One point of view is that the injury may 'uncover' BP antigens which were previously inaccessible to the immune system (13), or alters these antigens in BMZ, which becomes alien to immune cells (3). If this latter happens, this enhanced antigenicity of the basement membrane constituents leads to 'de novo' synthesis of autoreactive antibodies. On the other hand, some researchers propose a different, more likely theory which advocates that these patients already have autoantibodies directed towards BMZ components in low titers, insufficient to induce immunologic response (6). Complement system activation due to antigen-antibody binding is possible only in a proinflammatory milieu (2). If the tissue is injured, this prerequisite is met leading to blister formation because of the following: innate immune cells (such as macrophages, neutrophils and mast cells) are activated by non-antigen-specific pathways and heavily infiltrate the site; cytokines and chemokines are secreted; vasodilation increases concentration of autoantibodies (simultaneously increasing the affinity for binding to antigens); complement system is activated and matrix metalloproteinase 9 is released by leukocytes $(2,6,11)$. However, both of these two opposing hypotheses, the first advocating induction of autoimmunity, the second unmasking latent BP, are yet to be proven.

Interestingly enough, one might consider LBP arising in surgical scars, actually, in any traumatized site, as a real-life example of novel concept in dermatology, so called "immunocompromised district" (ICD) (4). Ruocco et al. were the first to introduce this term in 2009, as an expansion of an older concept of "locus minorisresistentiae" (LMR) 18. The previously described concept of LMR suggests that a certain body region is more prone to some diseases due to innate or acquired defense dysregulation, and that is why certain regions represent opportunistic localizations for a number of skin conditions thanks to pre-existing favoring conditions (19). Even more specific example of LMR would be Wolf's "isotopic response", where sites previously affected by herpes simplex virus, become susceptible to other infections, tumors or different immune dysregulation (20). As Ruocco described, ICD represents a site in which one disease predisposes development of a different, unrelated disease due to regional destabilization of neuro-immuno-cutaneous system (18), which can vary immensely in lapse of time, but is typically confined to the same area (4). It is important to point out that the term 'immunocompromised' indicates merely immunedysregulation (in either directions) and cannot be equaled with its reduction of it (19). In short, any interference with signaling pathways between nerve fibers, neuropeptides, 
neurotransmitters and immune cell receptors can alter regional immune response, and even though the affected area may look clinically normal after the causing agent has disappeared, this alteration can be permanent (19). Most often implicated exogenous factors that contribute to ICD are regional chronic lymphedema, herpetic infections, vaccinations, ionizing and ultraviolet radiation, thermal burns and different types of other physical injuries $(2,19)$.

In our opinion, in our patient, one 'disease' or rather tissue injury (surgery), caused immunological alteration that led to secondary disease (LBP), which would be another good example of ICD. Finally, we feel that this case demonstrates the need for clinicians' awareness of LBP which should be included in the differential diagnosis of localized bullous eruptions, especially if bullae are confined to surgical scars.

\section{Conclusion}

We presented a case of an otherwise healthy male adult with a rare localized variant of bullous pemphigoid around the surgical scar which developed 9 months after knee arthroplasty. BP was successfully treated with a topical corticosteroid.

\section{Abbreviations}

LBP - localized bullous pemphigoid

BP - bullous pemphigoid

DIF - direct immunofluorescence

BMZ - basement membrane zone

DIF-SS - direct immunofluorescence using salt-

split skin

$\mathrm{Hb}$ - hemoglobin

UVA - ultraviolet light A

UVB - ultraviolet light B

ICD - immunocompromised district

LMR - locus minorisresistentiae

\section{References}

1. Sneddon IB, Church R, Sparrow GP, Moynahan EJ. Localized pemphigoid. Br J Dermatol1976;95(Suppl 14):26-8.

2. Lo Schiavo A, Caccavale S, Alfano R, Gambardella A. Bullous pemphigoid initially localized around the surgical wound of an arthroprothesis for coxarthrosis. Int J Dermatol 2014;53(4):e289-90.

3. Kavak A, Parlak AH, Çetinkaya R, Tüzüner T. Bullous pemphigoid on an incision scar of total knee prosthesis. Indian J Dermatol 2006;51(1):70-2.

4. Baroni A, Piccolo V, Russo T, Chessa MA. Localized bullous pemphigoid occurring on surgical scars: an instance of immunocompromised district. Indian J Dermatol Venereol Leprol 2014;80(3):255.

5. Tarazona MJ, Mota AN, Gripp AC, Unterstell N, Bressan AL. Bullous pemphigoid and neurological disease: statistics from a dermatology service. An Bras Dermatol 2015;90(2):280-2.

6. Danescu S, Chiorean R, Macoyei V, Sitaru C, Baican A. Role of physical factors in the pathogenesis of bullous pemphigoid: case report series and a comprehensive review of the published work. J Dermatol 2016;43(2):134-40.

7. Freeman BD, Rubin BG. Bullous pemphigoid after prosthetic vascular graft placement. Surgery 1998;124(1):112-3.

8. Brick KE, Weaver CH, Lohse CM, Pittelkow MR, Lehman JS, Camilleri MJ, et al. Incidence of bullous pemphigoid and mortality of patients with bullous pemphigoid in Olmsted County, Minnesota, 1960 through 2009. J Am Acad Dermatol 2014;71(1):92-9.

9. Langan SM, Smeeth L, Hubbard R, Fleming KM, Smith CJ, West J. Bullous pemphigoid and pemphigus vulgaris-incidence and mortality in the UK: population based cohort study. BMJ 2008;9:337:a180.

10. Bastuji-Garin S, Joly P, Lemordant P, Sparsa A, Bedane C, Delaporte E, et al. Risk factors for bullous pemphigoid in the elderly: a prospective case-control study. J Invest Dermatol 2011;131(3):637-43.

11. Lo Schiavo A, Ruocco E, Brancaccio G, Caccavale S, Ruocco V, Wolf R. Bullous pemphigoid: etiology, pathogenesis, and inducing factors: facts and controversies. Clin Dermatol 2013;31(4):391-9.

12. Delgado JC, Turbay D, Yunis EJ, Yunis JJ, Morton ED, Bhol $\mathrm{K}$, et al. A common major histocompatibility complex class II allele HLA-DQB1*0301 is present in clinical variants of pemphigoid. Proc NatlAcad Sci USA 1996;93(16):8569-71.

13. Anderson CK, Mowad CM, Goff ME, Pelle MT. Bullous pemphigoid arising in surgical wounds. $\mathrm{Br} \mathrm{J}$ Dermatol 2011;145(4):670-2.

14. Khandpur S, Verma P. Bullous pemphigoid. Indian J Dermatol Venereol Leprol 2011;77(4):450-5.

15. Orvis AK, Ihnatsenka V, Hatch RL. Bullous lesions on a skin graft donor site. J Am Board FamMed 2009;22(1):89-92.

16. Hafejee A, Coulson IH. Localized bullous pemphigoid 20 years after split skin grafting. Clin Exp Dermatol 2005;30(2):187-8.

17. Zeng R, Chen H, Jiang Y, Li M. Bullous pemphigoid after femur fracture surgery: a mere coincidence? Indian J Dermatol Venereol Leprol 2014;80(2):195.

18. Ruocco V, Brunetti G, Puca RV, Ruocco E. The immunocompromised district: a unifying concept for lymphoedematous, herpes-infected and otherwise damaged sites. JEurAcad DermatolVenereol 2009;23(12):1364-73.

19. Piccolo V, Baroni A, Russo T, Schwartz RA. Ruocco's immunocompromised cutaneous district. Int J Dermatol 2016;55(2):135-41.

20. Wolf R, Brenner S, Ruocco V, Filioli FG. Isotopic response. Int J Dermatol 1995;34(5):341-8. 


\section{Lokalizovani bulozni pemfigoid na mestu izvedene artroplastike kolena: prikaz slučaja}

\section{Sažetak}

Uvod. Lokalizovani bulozni pemfigoid (LBP) predstavlja retku varijantu buloznog pemfigoida čija tačna patogeneza još uvek nije razjašnjena.

Prikaz slučaja. Prikazujemo 74-godišnjeg pacijenta sa kutanim lezijama u trajanju od 3 meseca, kojesu se pojavile 9 meseci nakon artroplastike zgloba kolena. Pri pregledu, bile su uočljive bule napetog krova na desnom kolenu, lokalizovane oko operativnog cikatriksa, kao I erozije prekrivene krustama, uz pruritus na mestu lezija. Dijagnoza LBP postavljena je na osnovu direktnog imunofluorescentnog testa (konvencionalnog i na hemijski rascepljenoj koži). Primenjena je potentna topikalna kortikosteroidna terapija, što je dovelo do potpune rezolucije kožnih promena.

Diskusija.SmatramodasepojavaLBPkodnašegpacijenta može objasniti konceptom „imunokompromitovanog područja”, u kome jedna bolest (hirurškaintervencija) dovodi do izmene imunskog odgovora, što stvara preduslov za razvoj druge bolesti na istom mestu, u našem slučaju lokalizovanog buloznog pemfigoida.

Zaključak. U radu je prikazan slučaj inače zdrave muške osobe kod koje su se na mestu operativnog ožiljka, devet meseci nakon artroplastike kolenog zgloba, pojavile promene retkog lokalizovanog oblika buloznog pemfigoida, koje su uspešno lečene isključivo lokalnim kortikosteroidima.

\section{Ključne reči}

Bulozni pemfigoid; Kožne bolesti; Ožiljak; Imunokompromitovani bolesnici; Clobetasol; Artroplastika zgloba kolena 